\title{
Hydrothermal fields of the Piip submarine volcano, Komandorsky Back-Arc Basin: Chemistry and origin of vent mineralization and bubbling gas
}

\author{
PAVEL V. TOROKHOV \& YURI A. TARAN
}

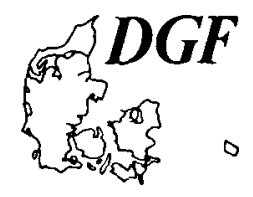

Torokhov, P. A. \& Taran, Yu. A.: Hydrothermal fields of the Piip submarine volcano, Koman-
dorsky Back-Arc Basin: Chemistry and origin of vent mineralization and bubbling gas. Bulletin
of the Geological Society of Denmark, Vol. 41, pp. 55-64, Copenhagen, 1994-03-30.
https://doi.org/10.37570/bgsd-1995-41-0-6

Active thermal vents of the Piip submarine volcano were studied in 1990 from aboard submersibles MIR 1 and 2. Samples of free gas and hydrothermal deposits were collected in the areas of thermal fluid discharge. Mineralogical, isotopic and microprobe studies of samples have shown, as the hydrothermal system cools, the high-temperature anhydrite association displayed at the surface is substituted by calcite-barite and later by calcite-barite-sulfide assemblages. The chemical and isotopic composition of gas and carbonates indicates the significant role of hydrocarbons from the sedimentary layers which, during the lowtemperature stage, stimulate the processes of bacterial sulphate reduction. The evolution of a simular hydrothermal system is traced in the Great Caucasus barite deposits.

Pavel V. Torokhov, Institute of Volcanology, Petropavlovsk-Kamchatsky, 683006, Russia. Yuri A. Taran, Institute of Volcanic Geology and Geochemistry, Petropavlovsk-Kamchatsky, 683006, Russia. August 28th, 1992.

\section{Introduction}

Active geothermal fields at the Piip submarine volcano, discovered during the 1984 cruise of R/V "Vulkanolog" (Seliverstov, Avdeiko, Ivanenko, Shkira \& Khubunaya 1986), have been studied using submersibles MIR 1 and 2 during the 1990 expedition of the R/V "Akademik Mstislav Keldysh" (Sagalevich, Torokhov, Matveenkov, Galkin \& Moskaliev 1992). Data on chemical composition of free gas and mineral sample recovered from the South and North summits of the volcano were presented in papers by Torokhov, Taran, Sagalevich, Pokrovsky \& Shabayeva (1991) and Taran, Torokhov, Pokrovsky \& Shabayeva (1992). The geochemistry of the hydrothermal sulfides is described by Torokhov (1992). In this paper a preliminary model of hydrothermal activity of Piip volcano is given on the basis of the present geochemical and mineralogical data.

\section{Geological setting}

The Piip submarine volcano is located at latitude $55^{\circ} 23^{\prime} \mathrm{N}$ and longitude $167^{\circ} 15^{\prime} \mathrm{E}$ and belongs to a large volcanic massif north ot the Komandorsky Islands in the western Aleutians. The rift basin where the Vulkanologov Massif
(Fig. 1) and Piip volcano are situated is characterized by NNE trending normal faults with spreading parallel to the strike-slip boundary between the Pacific and North American plates (Baranov, Seliverstov, Muravyev \& Mazurov 1991). Some petrological and geochemical studies of volcanic rocks collected from this area have been performed by Romick, Tsvetkov, Seliverstov \& Baranov (1990). The volcano is composed of high-magnesian hornblende-bearing dacites. This portion of the Bering Sea is characterized by high rates of sedimentation with the volcano having formed over a 1 to $2 \mathrm{~km}$ thick sediment layer (Seliverstov, Baranov, Egorov \& Shkira 1988). Probably, the most recent eruption of the Piip volcano occurred about 500 years ago, according to tephrochronological data (Seliverstov, Gavrilenko \& Kirianov, 1989).

\section{Hydrothermal fields: position and material}

The Piip volcano has two distinct summits (North and South), and represents two isolated cones, probably, of different ages (Figs 1 and 2). The hydrothermal activity was observed at both summits from aboard the submersible MIR. At each summit the hydrothermal activity has its own specific features. 


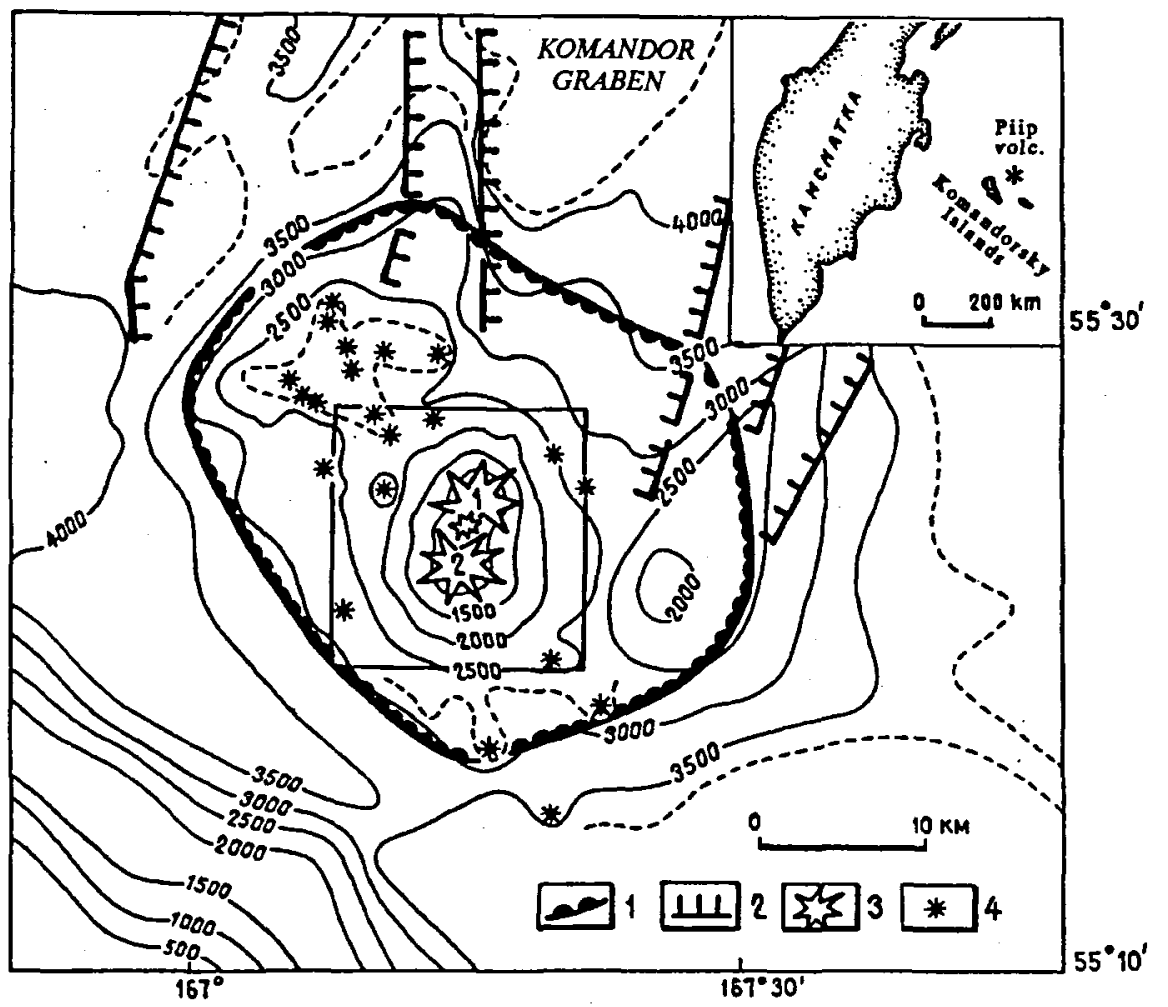

Fig. 1. The area of Vulkanologov Massif (modified from Seliverstov et al. 1988); The Piip volcano is in the square. 1 , boundary between sediments and volcanic edifice from seismic data; 2 , normal faults; 3 , peaks of the volcano (1) North, (2) South; 4, volcanic domes.

\section{North Peak}

The North Peak of the volcano, mapped from detailed echosounding data obtained during the expedition of the $\mathrm{R} / \mathrm{V}$ "Vulkanolog", has two separate domes, western and eastern, linked through a $400 \mathrm{~m}$ isobath. The western slope of the volcano is buried under right-angled dacite blocks at a depth of $700 \mathrm{~m}$. Towards the top the size of blocks gradually increases and at a depth of $360 \mathrm{~m}$ the western dome is like a pile of gigantic masonry. This dome is a dacitic extrusion, and has an asymetric structure; a gently sloping outer flank changes into a nearly vertical wall which faces the centre of the volcano.

The eastern and part of the southern slopes of the dome are covered with pumice, volcaniclastic and hydrothermal deposits. The most active hydrothermal exhalations have been discovered on these slopes. The summit of the eastern dome lying at a depth of $380 \mathrm{~m}$ is almost entirely overlapped by hydrothermal deposits and in its upper part large blocky dacite outcrops have been found extending in a ridge towards the northeast. The hydrothermal activity on the northern summit is mainly concentrated above a $450 \mathrm{~m}$ isobath. No visible seepages were observed below this depth. However, the seabed is covered with bacterial mats associated with fluid supply; these were observed at a depth of $650 \mathrm{~m}$ on the SSW slope.

The most extensive bacterial mat cover was found at depths of $600-650 \mathrm{~m}$. There are areas here as much as

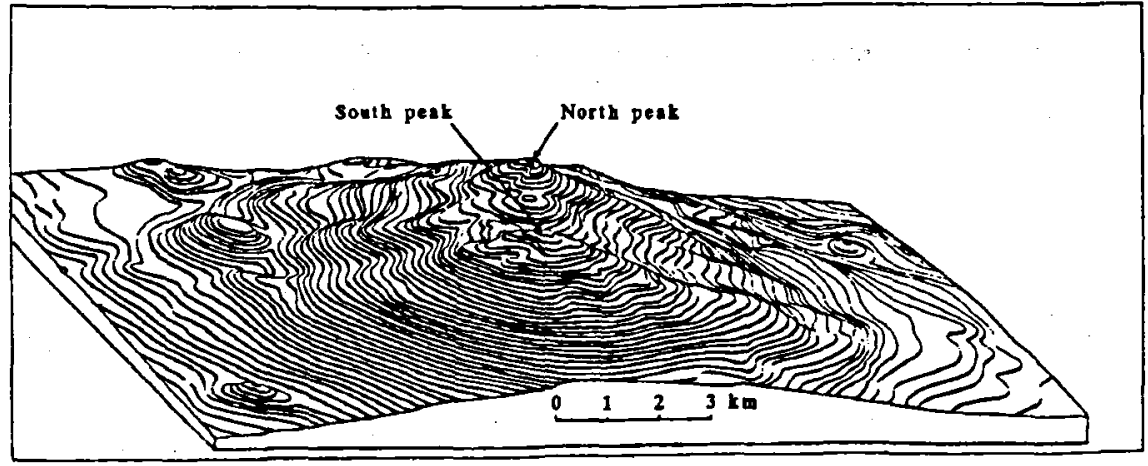

Fig. 2. Blockdiagram of the Piip volcano (after Seliverstov et al. 1988) showing the location of sampling sites. 


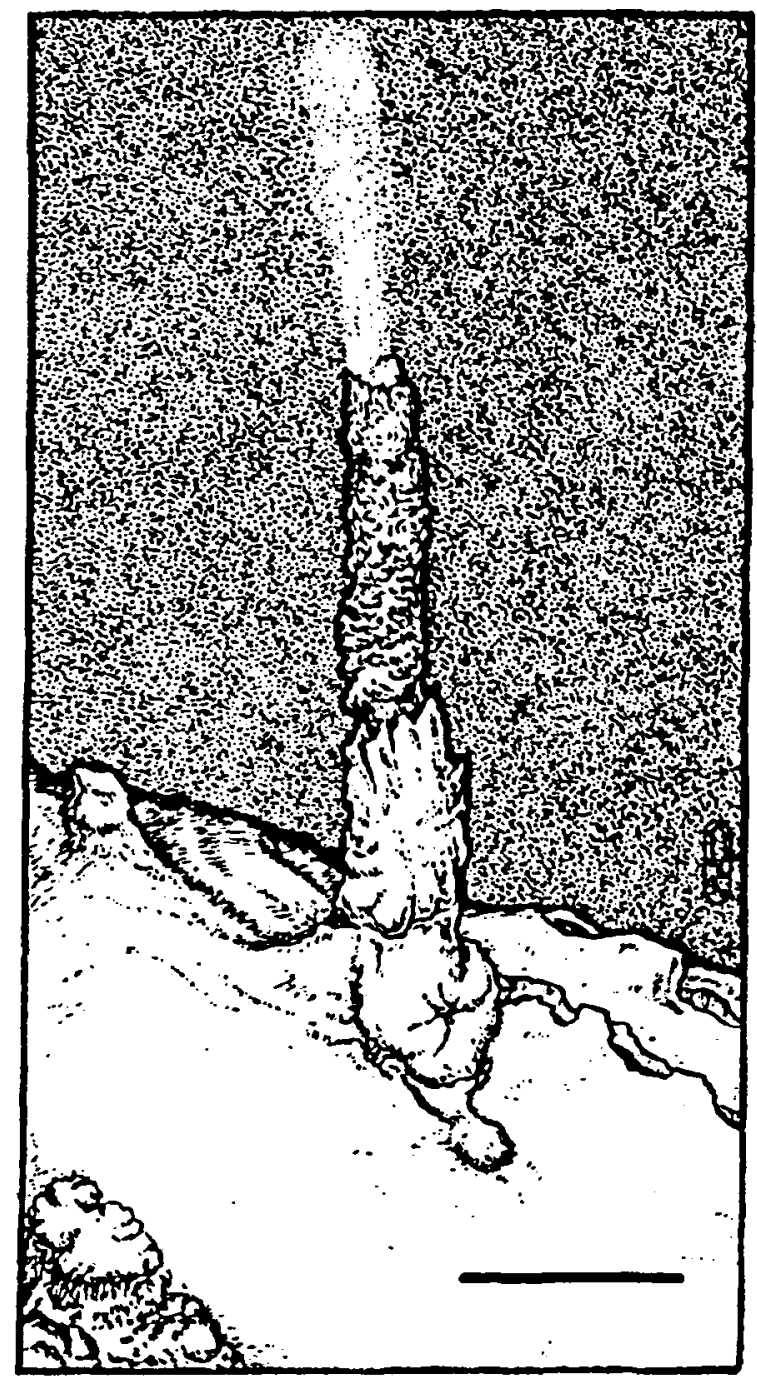

Fig. 3. The anhydrite chimney from the field of the North Peak (after Sagalevich et al. 1992), scale is $0.5 \mathrm{~m}$.

$100 \mathrm{~m}^{2}$ entirely covered with bacterial mats. Boundary lines of mats on the ground were not drawn but the area explored (a few hundreds of square meters) allows us to suggest a significant fluid supply in this region. Near the base of the extrusive dome, zones of hydrothermal fluid seepages are marked by bacterial mats covering the talus blocks. In some places one can observe maars filled with warm water that seeps through the blocks. No hydrothermal deposits are found at the places where warm water issues. The only place at which the hydrothermal fluid goes immediately into the benthic water and is easy for study is the eastern dome of the volcano. Four sites of local discharge of thermal waters have been discovered here. Discharge occurs through $1.5 \mathrm{~m}$ high anhydrite chimneys, $10-15 \mathrm{~cm}$ in diameter (Fig. 3).

Detailed studies were conducted at one of the hydro- thermal springs to clarify the characteristics of the thermal fluid. The water depth at the place of fluid issue was $382 \mathrm{~m}$. The flow rates of the water and free gas were estimated to be 50-100 and 2-5 1 per minute, respectively, for this depth. The temperature of the discharge is estimated to be near the boiling point at this depth $\left(250^{\circ} \mathrm{C}\right.$, Fig. 4$)$, because the discharge is visible as a shimmering (steam-water?) mixture. Here at the base of the chimney, the free gas was samples in a glass bottle which was placed immediately after sampling into a metal container filled with seawater. In addition to bubbles slowly rising from the basement of the edifice, significant amounts of gases are emmited from the summit of the hydrothermal edifice, but the bubbles entering here, at a distance of half meter from the spring, were not visible from the submersible. The disappearence of the bubbles may be related to steam condensation and $\mathrm{CO}_{2}$ dissolution.

Mineral assemblages collected from the North Peak vent areas also imply the high temperature of the fluid. As was mentioned above, the chimneys are composed of almost pure anhydrite and are formed near the hightemperature fluid discharge. Anhydrite, as was stated by Kusakabe, Mayeda \& Nakamura (1990), results from mixing of seawater containing sulfate ions with thermal fluid enriched in calcium in a temperature range of 180 $360^{\circ} \mathrm{C}$. Under laboratory conditions seawater saturation with anhydrite has been achieved by heating it up to $110^{\circ} \mathrm{C}$ (Glater \& Schwartz, 1976). A discovery of a $1.5 \mathrm{~m}$ long anhydrite chimney is a good illustration of the described process. Judging from the small variation in chimney diameter (Fig. 3), anhydrite was precipitated solely near the chimney orifice, in a mixing zone. Fragments of its debris lie around the chimney, and the seabed for a radius of 2-3 $\mathrm{m}$ around the sites of hydrothermal

\section{Temperature $\left({ }^{\circ} \mathrm{C}\right)$}

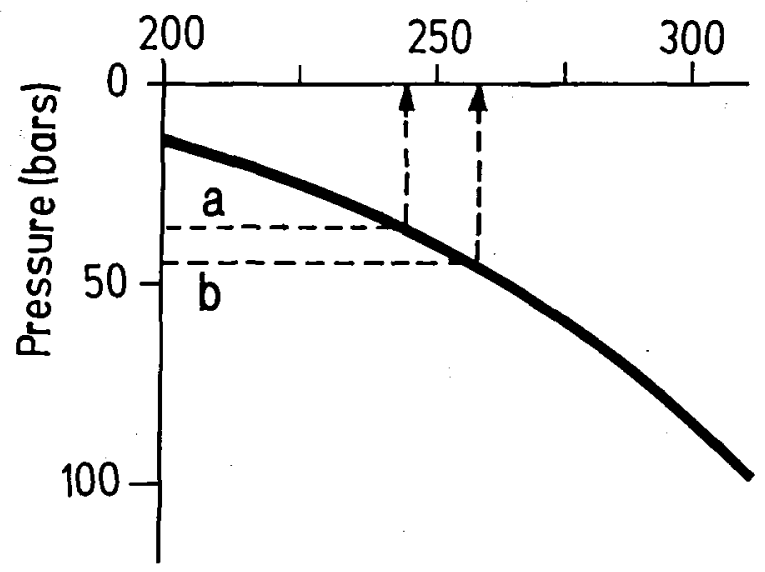

Fig. 4. The two-phase curve for a $3,2 \mathrm{wt} . \% \mathrm{NaCl}$ solution (after Bischoff \& Rosenbauer 1988), showing boiling temperature for the depths corresponding to hydrostatic pressure at (a) North and (b) South Peaks. 


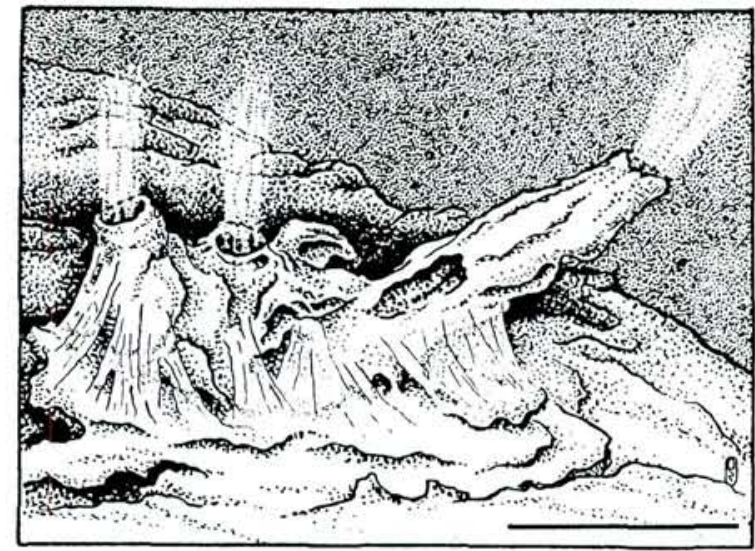

Fig. 5. The aragonite chimney from the South Peak (after Sagalevich et al. 1992), scale is $5 \mathrm{~cm}$.

discharge is covered with white mineral assemblages. A crust collected within $1 \mathrm{~m}$ of the basement of the chimney is represented by well crystallized gypsum looking like rice porridge (sample 2322-2). This sample also contains $30 \%$ of anhydrite which is apparently related to secondary alteration and the presence of equilibrium in an anhydrite-gypsum-water system. Holland \& Malinin (1979) have shown that at pressure of 50 bars such an equilibrium occurs at temperature of $60-70^{\circ} \mathrm{C}$. The surface of the seafloor far from sites of intense hydrothermal discharge is covered with loose deposits with a typical Fe-ochreus color. A sample collected in this zone (sample $2322-4$ ) is represented by amorphous silica, pyrite and kaolinite.

\section{South Peak}

The South Peak is outlined by the $450 \mathrm{~m}$ isobath. It is located 2.1 nautical miles from the North Peak and separated by a saddle with a maximum depth of $650 \mathrm{~m}$. The slopes of the south volcanic edifice, beginning from a depth of $700 \mathrm{~m}$, are composed of dacitic pumice often overlapped by a layer of sediments. The character of the exposures indicates the lack of massive dacites both on the slopes and at the summit of the volcano. The summit is dissected at a depth of $500 \mathrm{~m}$ by a series of open
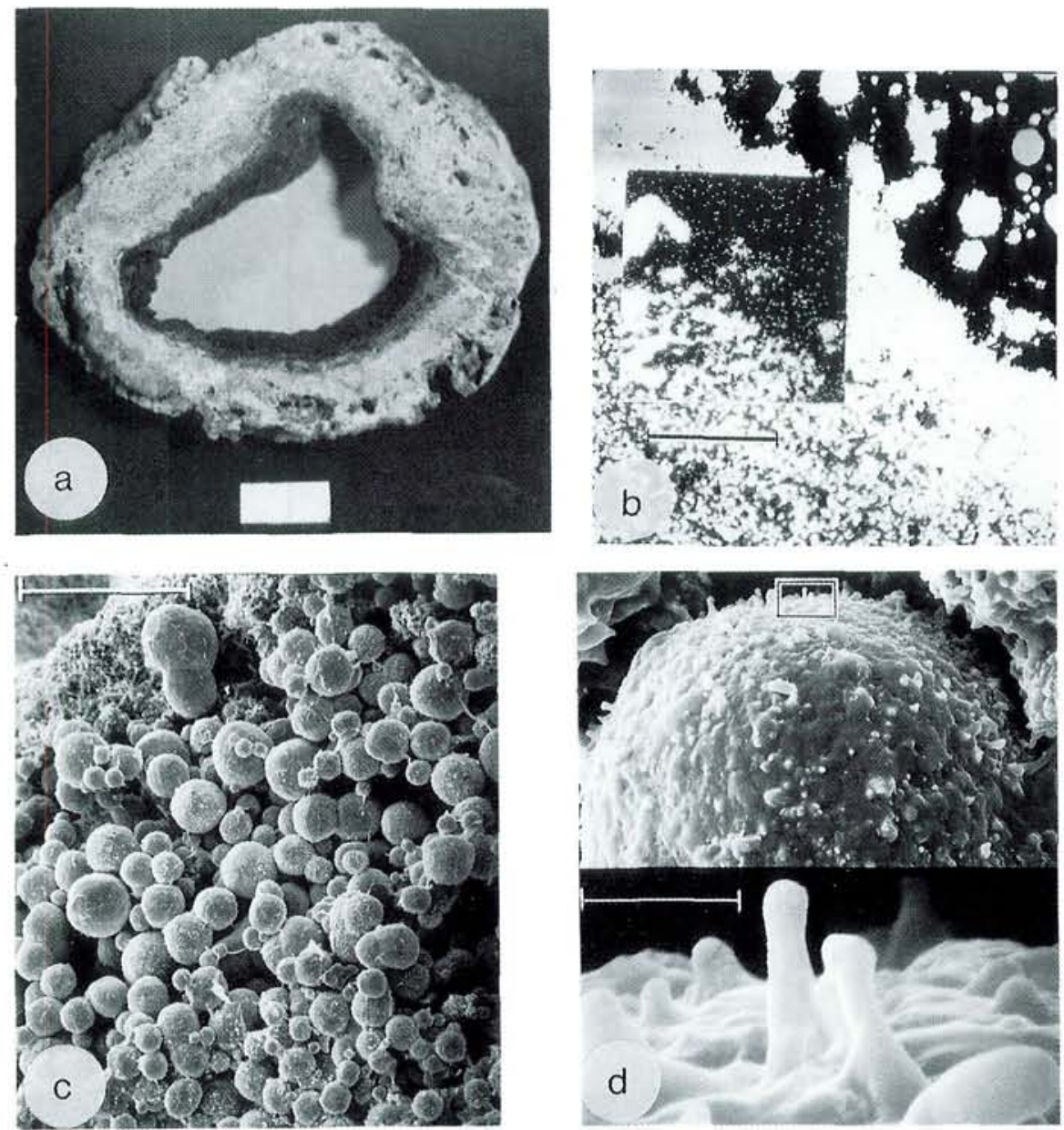

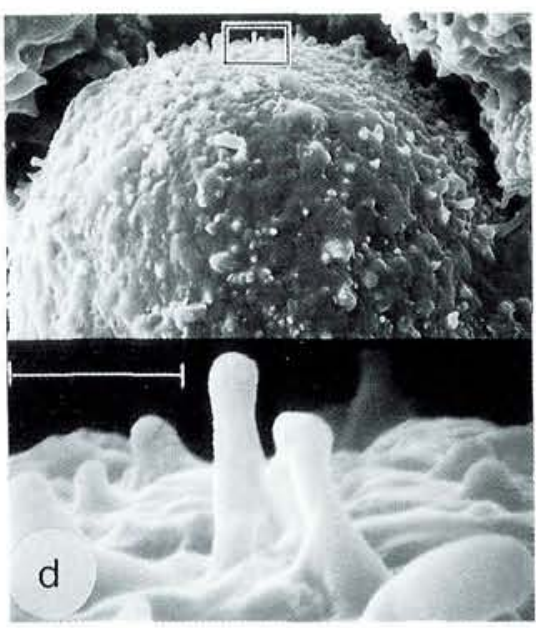

Bulletin of the Geological Society of Denmark
Fig. 6. The enrichment in pyrite of fluid channel inside aragonite chimney similar to that shown in Fig. 5. Photos is taken using electron microprobe and scanning electron microscope. a, the slice of aragonite chimney showing pyrite incrustation in the channel, scale is 1 $\mathrm{cm}$; b, aragonite-pyrite boundary in the reflection electrons, in the "window" $\mathrm{K}_{\alpha-\mathrm{Ca}}$, scale is 100 microns; c, the loose globular pyrite from the interior of the fluid channel, $\times 200$, scale is 150 microns; $d$, the surface of the globule with plumbs, $\times 2200$, scale is 13.6 microns. 
Table 1. Comparison of the gas composition from the Piip submarine volcano and other low- and high-temperature submarine gas discharges.

\begin{tabular}{|c|c|c|c|c|c|c|c|}
\hline Location & $\stackrel{1}{\text { Gas hydrate }}$ & $\underset{\text { volcano }}{2}$ & $\begin{array}{c}3 \\
\text { Guaymas } \\
\text { Basin }\end{array}$ & $\begin{array}{c}4 \\
\text { Mid } \\
\text { Okinawa } \\
\text { Trough }\end{array}$ & $\begin{array}{l}5 \\
\text { Bay of } \\
\text { Plenty }\end{array}$ & $\stackrel{6}{\text { SJFR }}$ & $\begin{array}{c}7 \\
\text { EPR } \\
21^{\circ} \mathrm{N}\end{array}$ \\
\hline $\begin{array}{l}\mathrm{CH}_{4} / \mathrm{H}_{2} \\
\mathrm{CH}_{4} / \mathrm{C}_{2+}\end{array}$ & $\begin{array}{l}1.5 \times 10^{5} \\
2.2 \times 10^{3}\end{array}$ & $\begin{array}{c}8 \times 10^{4} \\
260\end{array}$ & $\begin{array}{r}330 \\
78\end{array}$ & - & $\begin{array}{c}714 \\
-\end{array}$ & $\begin{array}{l}0.22 \\
330\end{array}$ & $\begin{array}{c}0.1 \\
2 \times 10^{3}\end{array}$ \\
\hline & \multicolumn{7}{|c|}{ carbon isotopes per mill PDB } \\
\hline $\begin{array}{l}\delta^{13} \mathrm{C}-\mathrm{CH}_{4} \\
\delta^{13} \mathrm{C}-\mathrm{CO}_{2}\end{array}$ & $\begin{array}{c}-54.6 \\
-\end{array}$ & $\begin{array}{l}-48.7 \\
-21.9\end{array}$ & $\begin{array}{r}-50.8 \\
+2.7\end{array}$ & $\begin{array}{l}-40 \\
-4.8\end{array}$ & $\begin{array}{r}-28.2 \\
-5.0\end{array}$ & $\begin{array}{r}-20.8 \\
-4.4\end{array}$ & $\begin{array}{l}-16 \\
-7.0\end{array}$ \\
\hline
\end{tabular}

1, Paramushir spring, gas-hydrate (Leyn et al. 1989); 2, free gas from the northern thermal field (Torokhov et al. 1991); 3, uncondensable fraction of dissolved gas (Welhan \& Lapton 1987); 4, free gas bubbles (Sakai et al. 1990); 5 , bubble gas (Lyon et al. 1977); 6, south vents of Juan de Fuca Ridge, dissolved gas (Evans et al. 1988); 7, East Pacific Rise, $21^{\circ} \mathrm{N}$ (Welhan \& Craig 1983, Welhan 1988).

fissures trending approximately north-south. The general strike of the widest tectonic disturbances is $340^{\circ}$.

Hydrothermal activity of the South Peak drastically differs from that of the North Peak. It is concentrated here along open fissures. Vent fluid, with a lower temperature

Table 2. Description of samples recovered from the Piip submarine volcano and their isotope data; $\delta^{34} \mathrm{~S}(\%, \mathrm{CD}) ; \delta^{13} \mathrm{C}(\%$, $\mathrm{PDB}) ; \delta^{18} \mathrm{O}(\%$, SMOW). After Sagalevich et al. (1992), Torokhov et al. (1991), and Taran et al. (1992).

\begin{tabular}{|c|c|c|c|}
\hline Sample & Location & $\begin{array}{l}\text { Major minerals, } \\
\text { isotope dts }\end{array}$ & $\begin{array}{l}\text { Minor } \\
\text { minerals }\end{array}$ \\
\hline \multicolumn{4}{|l|}{ North Peak } \\
\hline $\begin{array}{l}2311-6 \\
396 \mathrm{~m}\end{array}$ & $\begin{array}{l}\text { fragment of } \\
\text { hydrothermal } \\
\text { chimney. }\end{array}$ & $\begin{array}{l}\text { anhydrite; } \\
\delta^{34} \mathrm{~S}:+22.6\end{array}$ & $\begin{array}{l}\text { gypsum, pyrite } \\
\text { barite }\end{array}$ \\
\hline $\begin{array}{l}2311-1 \\
382 \mathrm{~m}\end{array}$ & same & $\begin{array}{l}\text { anhydrite; } \\
\delta^{34} S:+22.4\end{array}$ & gypsum, pyrite \\
\hline $\begin{array}{l}2322-2 \\
382 \mathrm{~m}\end{array}$ & $\begin{array}{l}\text { deopsits around } \\
\text { anhydrite } \\
\text { chimney }\end{array}$ & $\begin{array}{l}\text { gypsum; } \\
\delta^{34} S:+22.3\end{array}$ & anhydrite \\
\hline $\begin{array}{l}2322-4 \\
380 \mathrm{~m}\end{array}$ & $\begin{array}{l}\text { siliceous } \\
\text { altered rock } \\
30 \mathrm{~m} \text { from } \\
\text { chimney }\end{array}$ & $\begin{array}{l}\text { amorphous } \\
\text { silica, pyrite; } \\
\delta^{34} S:-2.4\end{array}$ & $\begin{array}{l}\text { kaolinite, } \\
\text { goethite }\end{array}$ \\
\hline \multicolumn{4}{|l|}{ South Peak } \\
\hline $\begin{array}{l}2310-3 \\
580-450 \mathrm{~m}\end{array}$ & $\begin{array}{l}\text { dredged from } \\
\text { top of South } \\
\text { peak }\end{array}$ & $\begin{array}{l}\text { barite; } \\
\delta^{34} S:+27.5\end{array}$ & calcite \\
\hline $\begin{array}{l}2320-4 \\
498 \mathrm{~m}\end{array}$ & $\begin{array}{l}\text { fragment of } \\
\text { active chimney }\end{array}$ & $\begin{array}{l}\text { aragonite; } \\
\delta^{13} \mathrm{C}:-35.6 \\
\delta^{18} \mathrm{O}:+22.9 \\
\text { pyrite; } \\
\delta^{34} \mathrm{~S}:+9.2\end{array}$ & calcite \\
\hline $\begin{array}{l}2320-10 \\
489 \mathrm{~m}\end{array}$ & $\begin{array}{l}\text { near open } \\
\text { fracture with } \\
\text { fluid seepage }\end{array}$ & $\begin{array}{l}\text { barite; } \\
\delta S^{34}:+39.0\end{array}$ & $\begin{array}{l}\text { Fe-Mn } \\
\text { oxihydroxides }\end{array}$ \\
\hline $\begin{array}{l}2320-4 \\
450 \mathrm{~m}\end{array}$ & $\begin{array}{l}\text { hydrothermal } \\
\text { mound at top } \\
\text { of peak }\end{array}$ & $\begin{array}{l}\text { calcite; } \\
\delta^{13} \mathrm{C}:-28.8 \\
\delta^{18} \mathrm{O}:+19.9\end{array}$ & quarts, pyrite \\
\hline
\end{tabular}

than that at the North Peak, is supplied immediately from the fissures and from the $40 \mathrm{~cm}$ high hydrothermal chimneys (Fig. 5). The most intense hydrothermal activity is concentrated at the central part of the summit at depths of $450-460 \mathrm{~m}$. Here a $10 \mathrm{~m}$ high hydrothermal mound with chimneys consisting of calcium carbonate and barite was discovered. The inner wall of the aragonite chimney from the active hydrothermal spring is covered with a pyrite film (Fig. 6a). Three zones of pyritization of the channel have been identified (Fig. 6b). Single globules in aragonite are gradually substituted by a solid crust turning into a loose globular pyrite (Fig. 6c). A barite sample covered with a black film of hydrous ferric and manganese oxides (sample 2320-10) was collected several meters away from the central hydrothermal edifice. A further barite sample with admixed calcite was recovered by dredging (sample 2310-3) indicating a wide development of barite in addition to calcite. Pumice on the flank of the volcano is covered with a yellow nontronite film.

Just as at the North Peak, areas of the seabed are covered with bacterial mats, but they are not so large here.

Only the bivalve mollusc Caliptogena have been found (Sagalevich et al. 1992). It was discovered at a depth of $489 \mathrm{~m}$ along fissures traced by bacterial mats covering pumice which is dusted with sediments.

\section{Results and discussion}

\section{Gas Chemistry}

The analysis of the gas sample from the Piip volcano shows that methane is the major component of the gas:

$\mathrm{CH}_{4}=80.58$ vol\%; $\mathrm{C}_{2} \mathrm{H}_{6}=0.27$ vol\%; $\mathrm{C}_{3} \mathrm{H}_{8}=0.26$ vol\%; $\mathrm{i}-\mathrm{C}_{4} \mathrm{H}_{10}=0.0024 \mathrm{vol} \% ; \mathrm{n}-\mathrm{C}_{4} \mathrm{H}_{10}=0.0013$ vol\%; $\mathrm{CO}_{2}=1.35 \mathrm{vol} \% ; \mathrm{N}_{2}=16.75$ vol\%; $\mathrm{O}_{2}=0.73 \mathrm{vol} \% ; \mathrm{H}_{2}=$ $0.001 \mathrm{vol} \% ; \mathrm{Ar}=0.33 \mathrm{vol} \% ; \mathrm{He}=0.04 \mathrm{vol} \%$. The composition of the collected gas was compared with the gas composition of fluids from several other submarine 
Table 3. Results of electron microprobe analysis of pyrites, in weight percent.

\begin{tabular}{|c|c|c|c|c|c|c|}
\hline \multicolumn{2}{|c|}{ Sample } & $2322-4$ & $2311-6$ & 2311.6 & $2320-4$ & $2320-13$ \\
\hline \multicolumn{2}{|c|}{$\begin{array}{l}\text { Host } \\
\text { mineral }\end{array}$} & $\begin{array}{l}\text { amorphous } \\
\text { silica }\end{array}$ & anhydrite & barite & aragonite & calcite \\
\hline \multicolumn{2}{|c|}{$\begin{array}{l}\text { Number of } \\
\text { analyses }\end{array}$} & 19 & 7 & 12 & 18 & 10 \\
\hline $\mathrm{Fe}$ & $\frac{\mathrm{OR}}{\mathrm{X}}$ & $\begin{array}{c}39.5-46.7 \\
43.7\end{array}$ & $\begin{array}{c}43.8-45.1 \\
44.2\end{array}$ & $\begin{array}{c}35.7-40.0 \\
38.2\end{array}$ & $\begin{array}{c}42.0-43.9 \\
43.2\end{array}$ & $\begin{array}{c}41.9-45.8 \\
44.2\end{array}$ \\
\hline$S$ & $\frac{\mathrm{OR}}{\mathrm{X}}$ & $\begin{array}{c}51.6-53.6 \\
52.4\end{array}$ & $\begin{array}{c}50.5-52.5 \\
51.6\end{array}$ & $\begin{array}{c}47.4-50.5 \\
49.3\end{array}$ & $\begin{array}{c}48.6-51.3 \\
50.1\end{array}$ & $\begin{array}{c}50.4-52.7 \\
51.6\end{array}$ \\
\hline $\mathrm{Mn}$ & $\frac{\mathrm{OR}}{\mathrm{X}}$ & n.d. & $\begin{array}{c}0.0-0.31 \\
0.26\end{array}$ & $\begin{array}{c}0.0-0.40 \\
0.19\end{array}$ & $\begin{array}{c}0.0-0.08 \\
0.05\end{array}$ & $\begin{array}{c}0.0-0.57 \\
0.34\end{array}$ \\
\hline $\mathrm{Cu}$ & $\frac{\mathrm{OR}}{\mathrm{X}}$ & $\begin{array}{c}0.0-7.71 \\
2.80\end{array}$ & $\begin{array}{c}1.34-2.29 \\
1.77\end{array}$ & $\begin{array}{c}1.01-3.75 \\
1.78\end{array}$ & n.d. & $\begin{array}{c}0.12-2.85 \\
0.62\end{array}$ \\
\hline As & $\frac{\mathrm{OR}}{\mathrm{X}}$ & n.d. & $\begin{array}{c}0.0-1.10 \\
0.49\end{array}$ & $\begin{array}{c}1.62-2.48 \\
2.03\end{array}$ & $\begin{array}{c}2.46-4.90 \\
3.53\end{array}$ & $\begin{array}{c}0.10-1.0 \\
0.41\end{array}$ \\
\hline $\mathrm{Sb}$ & $\frac{\mathrm{OR}}{\mathrm{X}}$ & n.d. & $\begin{array}{c}0.0-0.06 \\
0.02\end{array}$ & $\begin{array}{c}1.63-3.20 \\
2.26\end{array}$ & $\begin{array}{c}0.51-2.20 \\
1.29\end{array}$ & $\begin{array}{c}0.0-0.58 \\
0.17\end{array}$ \\
\hline $\mathrm{Hg}$ & $\frac{\mathrm{OR}}{\mathrm{X}}$ & $\begin{array}{c}0.04-0.23 \\
0.10\end{array}$ & $\begin{array}{c}0.04-0.18 \\
0.08\end{array}$ & $0.96^{*}$ & $\begin{array}{c}0.30-1.02 \\
0.61\end{array}$ & $\begin{array}{c}0.0-0.29 \\
0.16\end{array}$ \\
\hline $\mathrm{Ag}$ & $\frac{\mathrm{OR}}{\mathrm{X}}$ & n.d. & $\begin{array}{c}0.0-0.18 \\
0.10\end{array}$ & $\begin{array}{c}2.63-6.27 \\
4.10\end{array}$ & n.d. & $\begin{array}{c}0.0-2.36 \\
1.01\end{array}$ \\
\hline$\Sigma$ & & 99.18 & 98.61 & 97.94 & 98.88 & 98.42 \\
\hline
\end{tabular}

$\mathrm{Pb}, \mathrm{Zn}, \mathrm{Cd}, \mathrm{Au}, \mathrm{Co}, \mathrm{Ni}, \mathrm{Se}, \mathrm{Te}$ are not detected (n.d.); ${ }^{*} \mathrm{Hg}$ only present in one analysis; $\mathrm{OR}=$ observed range; $\overline{\mathrm{X}}=$ mean value.

hydrothermal and non-hydrothermal fields (Table 1). The chemistry of the Piip volcano gas sample is similar to the chemistry of gas of the submarine Paramushir Spring from gas hydrate deposits (Lein, Galchenko, Pokrovsky, Shabayeva and Chertkova 1989; Chertkova and Stunzhas, 1989). It differs by its higher $\mathrm{H}_{2}$ content and a lower $\mathrm{CH}_{4} / \mathrm{C}_{2+}$ ratio. The comparatively high $\mathrm{He}$ concentration is typical of many of the natural gas discharges in Kamchatka that are related to sedimentary strata (Rozhkov \& Verkhovsky 1990). The high temperatures indicated for the North Peak discharges are not consistent with the low $\mathrm{H}_{2}$ and $\mathrm{CO}_{2}$ concentrations, in contrast to high-temperature fluids from the East Pacific Rise, $21^{\circ} \mathrm{N}$, Okinawa Through and other sites (Welhan \& Craig 1963; Sakai et al. 1990). The $\mathrm{C}_{2}-\mathrm{C}_{4}$ gases in fluids from the Piip volcano are predominantly alkanes with no alkenes. The $C_{1} / C_{2}$ ratio (260) is within the range of that for Guaymas Basin, but about one order of magnitude lower than that in the "abiogenic" gases from the East Pacific Rise, $21^{\circ} \mathrm{N}$ and the south vents of Juan de Fuca Ridge (Evans, White \& Rapp 1982; Welhan \& Lupton 1987) and in the gashydrate from the Paramushir Spring (Lein et al. 1989). The distribution of $\mathrm{C}_{2}-\mathrm{C}_{4}$ hydrocarbons differs from the nearly uniform $\mathrm{C}_{2}-\mathrm{C}_{4}$ abundances in the EPR gases (Welhan \& Lupton 1987), and the very distinct $\left(\mathrm{CH}_{4} / \mathrm{C}_{2} \mathrm{H}_{6}=\right.$ 2300) distribution for the Paramushir gas (Lein et al. 1989). It is closer to the "thermogenic" distribution in gases from Guaymas Basin (Welhan \& Lupton 1987) and to that commonly occurring in geothermal gases (Des Marais, Stallard, Nehring \& Truesdell 1982; Taran 1988).
Carbon isotopes in $\mathrm{CO}_{2}$ and $\mathrm{CH}_{4}$

Istopic characteristics of the gas and mineral samples are given in Tables 1 and 2 . Methane is considerably enriched in ${ }^{13} \mathrm{C}$ compared to the gas hydrate $\mathrm{CH}_{4}$ from the Paramushir submarine seepage (Lein et al. 1989) whereas its isotopic composition is similar to $\mathrm{CH}_{4}$ from Guaymas fluids (Welhan \& Lupton: 1987). The $\mathrm{CH}_{4}$ and other hydrocarbon gases appear to be characterized by a large proportion of thermocatalytically-derived gases. This suggestion is confirmed by the low $\delta^{13} \mathrm{C}$-value of $\mathrm{CO}_{2}$ $(-21.9 \%)$, which may result from a high degree of thermodegradation of organic matter in the sediments which have a $\delta^{13} \mathrm{C}$ ranging from -25 to $-22 \%$ (Galimov \& Simoneit 1982) or from a thermocatalytic oxidation of hydrocarbons (methane) with $\Delta^{13} \mathrm{C}\left(\mathrm{CO}_{2}-\mathrm{CH}_{4}\right)$ ranging from 25 to $30 \%$ (Schoell 1984).

\section{${ }^{13} \mathrm{C}$ and ${ }^{18} \mathrm{O}$ in carbonates}

Carbonate chimneys (Fig. 4) and fragments of massive calcite deposits recovered from the southern field are also significantly depleted in ${ }^{13} \mathrm{C}$ isotope. These carbonates are similar in their isotopic composition to calcites from North Sea seepages (Hovland \& Judd 1988) and from the Paramushir Spring (Lein et al. 1989). The oxygen isotopic composition of these samples indicates isotopic equilibrium temperatures of $52^{\circ} \mathrm{C}$ and $72^{\circ} \mathrm{C}$ (calcite-seawater fractionation, Friedman \& O'Neil 1977) and these values probably reflect the real temperatures of the fluid 
outflows at the South Peak. A likely source of light carbon $(-29$ and $-36 \%$ ) in the southern field carbonates is $\mathrm{CO}_{2}$ derived from biogenic oxidation of methane (Hovland \& Judd 1988; Lein et al. 1989).

\section{Sulfur isotopes}

The high-temperature sulfates (anhydrite and gypsum) from the North Peak and the low-temperature sulfates (barites) from the South Peak differ significantly in their sulfur isotopic compositions. Anhydrite from the northern field is slightly enriched in ${ }^{34} \mathrm{~S}$ isotope, and is considered to have formed under open conditions with respect to marine sulfate. The slight ${ }^{34} \mathrm{~S}$ enrichment may be due to a small degree of contamination by some heavier sulfate derived from either high-temperature sulfate reduction under hydrothermal conditions or by sulfate reduction in the vicinity of the venting system (Woodruff \& Shanks 1988; Kusakabe et al. 1990). The pyrite from the argillaceous altered rock sample has a sulfur isotope composition $(-2.4 \%)$ in the range of that of magmaderived hydrogen sulfide (Vinogradov 1980). Sulfur minerals of the southern field have formed under distinctly different conditions. Barites, recovered from this lowtemperature field along active fractures associated with a visible seepage of fluid possibly formed by cooling of a barium-rich solution containing a sufficient amount of heavy sulfate. This barium sulfate, with $\delta^{34} S$ up to $39 \%$ o could be formed under closed conditions as a result of sulfate reduction accompanied by organic carbon or methane oxidation. Hence, we have isotopically light carbon in carbonate precipitates, and heavy sulfide and sulfate minerals (pyrite: $\delta^{34} S=+9.2 \%$; barites: $\delta^{34} S=+27$ and $+39 \%$ o). Hydrogen sulfide and sulfate with similar $\delta^{34} S$ is discharged from high and low temperature vents of the JADE and CLAM submarine fields, Okinawa Trough (Sakai et al. 1990; Gamo, Sakai, Kim, Shitashima \& Ishibashi 1991). On the other hand, the presence of such heavy sulfates may indicate that seawater circulation within the southern field is not deep and aquifer temperatures are not high, because sulfate is not completely lost by anhydrite precipitation and by sulfate reduction during seawater-rock interaction.

\section{Sulfide chemistry}

The five pyrite varieties identified in the samples differ in their combinations and concentrations of admixture elements, morphology of aggregates and paragenetic associations (Table 3 ).

Densely impregnated microcrystalline pyrite, which is syngenetic to amorphous silica, (sample 2322-4), occurs as aggregates $0.1-0.2 \mathrm{~mm}$ in size. Copper, the major coexisting element, is unevenly disseminated in the crystals. Pyrite, which in association with anhydrite, represents the major admixed component, contains copper and arsenic (sample 2311-6).

$\mathrm{FeS}_{2}$ which is syngenetic to the barite inclusions also contains silver in concentrations reaching $6 \%$. The authors have not previously encountered such a concentration. The distribution of the admixed elements is concentrically zoned. The sizes of collected aggregates having a colloform-dendritic structure range from 0.1 to $0.01 \mathrm{~mm}$.

$\mathrm{FeS}_{2}$ which encrusts the aragonite chimney contains the highest concentration of mercury and arsenic (sample $2320-4)$. The distribution of admixtures in globules is concentrically zoned. Microscope study of globular pyrite has shown that its surface has no traces of crystallization. Well-preserved plumbs (Fig. 6d) indicate that during sampling sulfides have been at the stage of ferrosulfide gel fall (Kitaenko 1989).

Massive calcite which, judging from its cavemous structure and the hydroxide film, has formed earlier, contained single pyrite framboids $0.15-0.05 \mathrm{~mm}$ in size. However, as distinct from pyrite from the aragonite chimneys, here the major admixtures are silver, copper and arsenic. It is noteworthy that the composition of these pyrites is remarkably similar to the composition of pyrites extracted from the North Peak sulfates. These pyrites are likely to have formed also during the hightemperature stage. During the subsequent stages, due to sulfate reduction, sulfates could entirely be substituted by calcium carbonate; at the same time sulfides maintained their primary composition.

Isotopic studies have shown the significant role of organic matter of the sediments in the hydrothermal process. Previously, using sulfides from hydrothermal vents in the Guaymas Basin as an example, it has been shown that the presence of hydrocarbons in the solution increases the migrational capability of metals in the form of metal-organic complexes (Lein, Galchenko, Grinenko, Ulyanova, Voropayeva \& Guzhova 1988) and the sedimentary strata act as suppliers of some metals. The consequence of the process is a large variety of mineral phases in the hydrothermal deposits compared with hydrothermal deposits from the zones where sedimentary strata are lacking (Lisitsin, Bogdanov \& Gurvich 1990).

The enrichment of sulfides from the Piip volcano in admixed elements appears to result also from metal transfer in the form of metal-organic complexes. Mercury, present in all the pyrites studied may be due to mercury degassing of the Earth (Ozerova 1977) along the fault to which the Piip volcano is structurally confined (Seliverstov et al. 1988). The lack of other sulfides in collected samples may be related to the shallow depths in the region of hydrothermal discharge which lead to a temperature limitation (boiling of rising fluid) to form $\mathrm{Cu}$ and $\mathrm{Zn}$ sulfides (Krasnov 1987). Under such conditions, a major ore body should be formed at the contact with sediments and within the volcanic edifice.

\section{Hypothetical model}

The data obtained allow the development of a hypothetical model for the Piip hydrothermal system. Seawater 


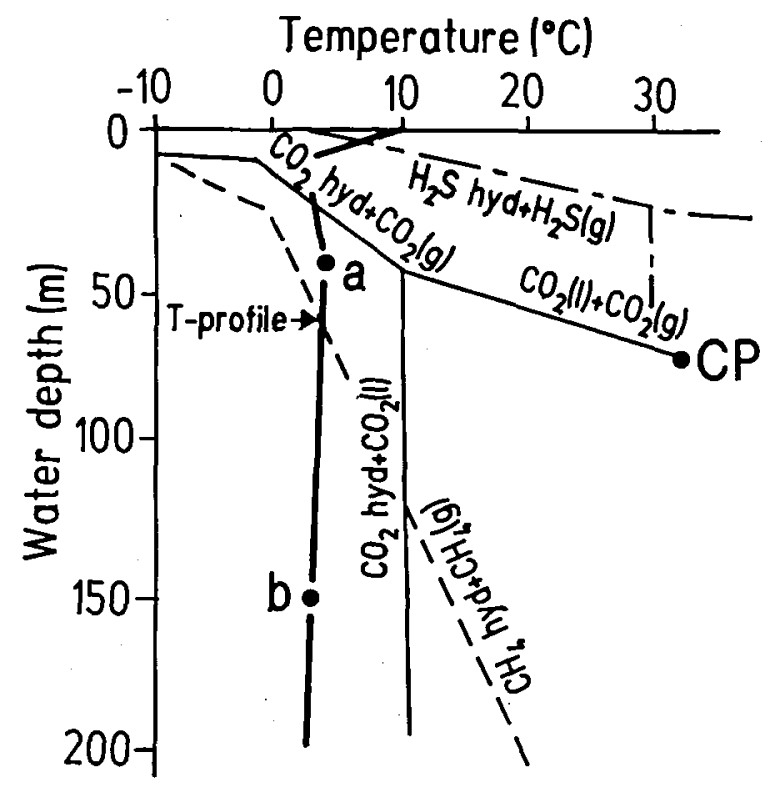

Fig. 7. Phase diagram of $\mathrm{CH}_{4}, \mathrm{CO}_{2}$ and $\mathrm{H}_{2} \mathrm{~S}$ hydrates stability (after Sakai et al. 1990) and depth-temperature profile in the water column above the Vulkanologov Massif (after Torokhov 1991). Points: a, depth of the Piip volcano fields; $b$, the depth of JADE field; CP-critical point.

circulating within the edifice creates a flow which draws up pore waters rich in hydrocarbon gases from the surrounding sedimentary strata. Due to the falling hydrostatic pressure when migrating to the summit, a free gas phase may form in the pore waters and, under the corresponding pressure and temperature conditions, gas hydrates may form (Fig. 7). The integrity of the gas hydrate layer is broken by the rising hydrothermal fluids which appear in the near-bottom water as discharges of gas bubbles. The effect of gas hydrate destruction in the region of hydrothermal discharge was previously studied in detail in the Izena Cauldron (Sakai et al. 1990). $\mathrm{CO}_{2-}$ rich gas bubbles seeping through pumice were collected here at a depth of $1.5 \mathrm{~km}$. It is noteworthy that the depth of sampling corresponds to the pressure at which, in the case of heating, $\mathrm{CO}_{2}$ gas hydrate is destroyed first (Fig. 7). Gas from the Piip volcano, enriched in methane, was collected at pressures at which $\mathrm{CH}_{4}$-hydrate is destroyed first. The effect of gas hydrate destruction and its further migration separated from high-temperature fluid seems to explain the lack of a high-temperature component in our sample. The high-temperature fluid discharging here forms anhydrite chimneys and gypsum-anhydrite deposits (Fig. 8). At the same time the temperature of the anhydrite formation is limited "from the top" by the boiling point (Fig. 4). The temperature of the fluid decreases as the magma cools. At temperatures above $200^{\circ} \mathrm{C}$ the solubility of $\mathrm{CaSO}_{4}$ becomes essentially higher than that of $\mathrm{BaSO}_{4}$ (Uchameishvili \& Malinin 1986) which leads to the replacement of the mineral assemblage. In both cases sulfate ions are supplied from the surrounding seawater. However, our isotope studies have shown that sulfate-ions are supplied into anhydrite immediately in the zone of contact with the fluid, though barite also acquires sulfate ions from the hydrothermal fluid. As the magma body cools, a minor part of sulfate ions from seawater circulating within the edifice is precipitated as $\mathrm{CaSO}_{4}$ and the major portion participates in abiogenic sulfate reduction. At temperatures of above $100^{\circ} \mathrm{C}$ the bacterial sulfate reduction, stimulated by the presence of hydrocarbons in the fluid, apparently increases. Isotopically heavier sulfate and hydrogen sulfide precipitates as barite and sulfides.

The above mentioned hypothetical views recall the stages of barite formation in a deposit currently being mined in the Great Caucasus from Mid Jurrassic volcanogenic strata. Using the Chordi barite deposit as an example (Grineko, Zagryzhskaya \& Uchameishvili 1976; Uchameishvili \& Malinin 1986), two production stages were identified in the sequence of mineral formation. During the earlier production stage, there occurs a gradual replacement of the quartz-anhydrite mineral assemblage by the calcite-barite assemblage. At the same time, the $\delta^{34} \mathrm{~S}$ value of sulfate changes from the range of

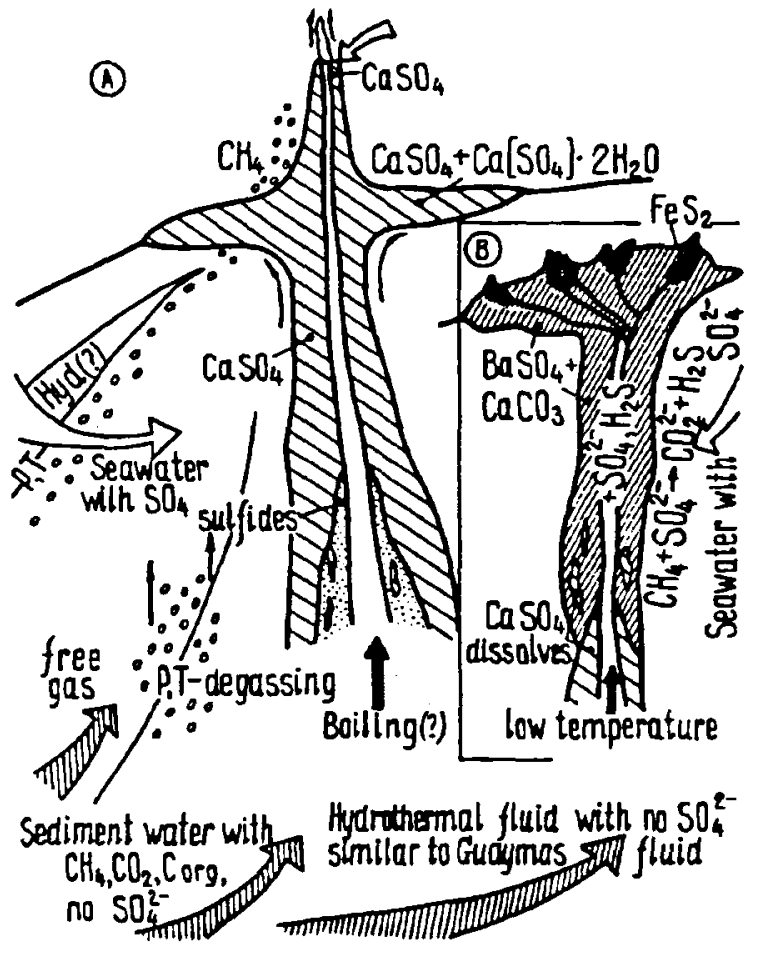

Fig. 8. Schematic diagram showing the processes in the hydrothermal systems of the Piip volcano; A, high-temperature stage of the North Peak; B, low-temperature stage of the South Peak. See text for further explanation. 
$+14-+16 \%$ (seawater sulfate at that geological period) to $+14-+21 \%$. The later production stage is characterized by the calcite-barite-sulphides assemblage and the $\delta^{34} S$ value of sulfate ranging from +20 to $+26 \%$ and the $\delta^{34} \mathrm{~S}$ sulfide ranging from +3.5 to $+7.8 \%$ o. From the mineral assemblage and from the tendency of sulfate and sulfide sulfur to become isotopically heavier, it is evident that the hydrothermal deposits of the Piip volcano are similar to those of the Chordi Prospect and apparently represents a modern analogue.

\section{Conclusions}

The results of studies on the Piip volcano thermal vents imply that sedimentary organic matter plays a substantial role in the hydrothermal process. The hot springs studied are at different stages of evolution. The features which resemble the thermal vents from the Guaymas Basin and Okinawa Trough are as follows:

(1) Similar $C_{1}-C_{4}$ hydrocarbon spectrum of gas corresponding to "thermogenic" gas. The values of $\delta^{13} \mathrm{C}$ of $\mathrm{CH}_{4}$ and $\Delta^{13} \mathrm{C}\left(\mathrm{CO}_{2}-\mathrm{CH}_{4}\right)$ also correspond to "thermogenic" gas.

(2) Similar spectrum of paragenetic non-ore mineral assemblages including anhydrite-barite for the high-temperature stage and calcite-barite for the low-temperature stage.

(3) Like sulfides from the Guaymas Basin, the pyrites studied contain significantly high concentrations of element admixtures such as $\mathrm{Cu}, \mathrm{Ag}, \mathrm{Hg}$, As and $\mathrm{Sb}$.

(4) There is a tendency for the replacement of the $\delta^{34} S$ value of sulfates, which is similar to the $\delta^{34} \mathrm{~S}$ value of $\mathrm{SO}_{4}$ of seawater at the high-temperature stage, by heavier values due to increasing sulphate reduction processes. A similar tendency is also observed in the ancient barite deposits in the Great Caucasus.

(5) Bacterial mat covers are widely developed.

At the same time, several distinctive features can be identified:

(1) Methane-rich gas bubbles from the high-temperature field do not contain a significant quantity of the magmatic components and, according to $\mathrm{CH}_{4} / \mathrm{H}_{2}$ values and $\delta^{13} \mathrm{C}$ of $\mathrm{CO}_{2}$, are similar to gas hydrates, e.g. from the Paramushir Region and Middle America Trench (DSDP, Leg 84, see Kvenvolden \& McDonald 1985).

(2) Barites and pyrites, which formed at the low-temperature stage, have remarkably heavy $\delta^{34} \mathrm{~S}$ values for $\mathrm{BaSO}_{4}$ and $\mathrm{FeS}_{2}$.

(3) Deposits formed at the high-temperature stage contain a low $(<1 \%)$ concentration of sulfides and do not form typical black or white "smokers".

(4) All the studied iron sulfides occur as pyrite, unlike sulfides from the Guaymas Basin where they occur only as pyrrhotite.

(5) The benthic fauna on the surface of the hydrothermal chimneys is absolutely absent.

\section{Acknowledgements}

We wish to thank A. M. Sagalevich, L. I. Moskalev, D. V. Vasiliev, N. L. Shashkov, Galkin and A. Y. Saidov and the crew of "Akademik Mstislav Keldysh" for their help in collecting the samples used in this study. We also thank L. F. Serkova for her help in preparing the manuscript.

\section{Dansk sammendrag}

Det foreliggende arbejde præsenterer en geokemisk og mineralogisk undersøgelse af de thermale udslipsprodukter i form af gas og mineraliseringer fra de hydrothermale felter ved den undersøiske Piip vulkan i Komandorsky Bassinet. Mineralogiske, isotopiske og mikrosondeundersøgelser godtgør, at der under afkøling i det hydrothermale system sker en gradvis andring i de submarint dannede mineralselskaber. I høj-temperatur området er mineraliseringerne karakteriseret af en anhydrit fase, som under den gradvise afk $\emptyset$ ling afløses af en calcit-barit fase og afsluttes med en calcit-barit-sulfid fase i lav-temperatur området. Isotop-analyser og geokemiske undersøgelser af de udskilte gasser og karbonater tyder på at biogene hydrokarbonater dannet $\mathbf{i}$ de overfladenære sedimenter spiller en vasentlig rolle for de hydrothermale processer og mineraliseringer i lav-temperatur området som følge af bakteriel sulfat reduktion.

\section{References}

Baranov, B. V., Seliverstov, N. I., Muravyev, A. V. \& Mazurov, E. L. 1991: The Komandorsky Basin as a product of spreading behind a transform plate boundary. Tectonophysics 199 , 237-269.

Bischoff, J. L. \& Rosenbauer, R. J. 1988: Liquid-vapor relations in the critical region of the system $\mathrm{NaCl}-\mathrm{H}_{2} \mathrm{O}$ from 380 to $415^{\circ} \mathrm{C}$ : A refined determination of the critical point and two-phase boundary of sea water. Geochim. Cosmochim. Acta 52, 2121-2126.

Chertkova, L. V. \& Stunzhas, P. A. 1989: Geochemistry of gases from the Paramushir submarine spring: NW flank of Paramushir Island, Kuriles. Volcanology and Seismology 3, 36-50. [In Russian].

Des Marais, D. J., Stallard, M. T., Nehring, N. L. \& Truesdell, A. H. 1982: Hydrocarbon production in the Cerro-Prieto geothermal field. 4th Symposium on the Cerro-Prieto Geothermal Field. Guadalahara, Mexico.

Evans, W. C., White, L. D. \& Rapp, J. B. 1988: Geochemistry of some gases in geothermal fluids from the Southern Juan de Fuca Ridge. J. Geophys. Res. 93, 15305-15313.

Friedman, I. \& O'Neil, J. R. 1977: Compilation of stable isotope fractionation factors of geochemical interest. In M. Fleischer (ed.), Data of Geochemistry, Chapter KK, U.S. Geol. Surv. Prof. Paper, 440-KK.

Galimov, E. M. \& Simoneit, B. R. T. 1982: Variation in $\mathrm{CH}_{4}$ and $\mathrm{CO}_{2}$-carbon isotope composition in the sedimentary section in Guaymas Basin, Gulf of California. Geochemistry Int. 19, 78-85.

Gamo, T., Sakai, H., Kim, E.-S., Shitashima, K. \& Ishibashi, J. 1991: High alkalinity due to sulfate reduction in the CLAM hydrotermal field, Okinawa Trough. Earth Planet. Sci. Lett. $107,328-338$. 
Glater, J. \& Schwartz, J. 1976: High-temperature solubilty of calcium sulfate hemihydrate and anhydrite in natural seawater concentrates. J. Chem. Eng. Date 21, 47-52.

Grinenko, V. A., Zagryzhskaya, G. D. \& Uchameishvili, N. E. 1976: Some questions concerning the genesis of hypogenic sulfate-sulfide associations of the southern slope of the Great Caucasus according to isotopic data of sulfur. Geokhimia 3, 336-346. [In Russian].

Holland, H. D. \& Malinin, S. D. 1979: Solubility and spreading of non-ore minerals. In H. L. Barnes and Wiley (eds), Geochemistry of Hydrothermal Ore Deposits. New York, Brisbane, 370-404.

Hovland, M. \& Judd, A. G. 1988: Seabed Pockmarks and Seepages. London/Dordrecht/Boston, 293 pp.

Kim, K. R., Welhan, J. A. \& Craig H. 1984: The hydrothermal vent fluids at $13^{\circ}$ and $11^{\circ} \mathrm{N}$ on the East Pacific Rise: Alvin 1984 results (abstract). EOS Trans. AGU 65, 973.

Kitaenko, A. E. 1989: Pyrite. In Typomorphism of Minerals. Moscow, Nedra, 355-362. [In Russian].

Kiyosu, Y. 1980: Chemical reduction and sulfur isotope effects of sulfate by organic matter under hydrothermal conditions. Chem. Geology 100, 47-56.

Krasnov, S. G. 1987: On the minimal depths of the sulfide ore formation on the ocean floor. Doklady Akademii Nauk SSSR 296, (5), 1188-1190.

Kusakabe, M., Mayeda, S. \& Nakamura, E. 1990: S, O, and Sr isotope systematics of active vent material from the Mariana backarc spreading axis at $18^{\circ} \mathrm{N}$. Earth. Planet. Sci. Lett. 100, 275-282.

Kvenvolden, K. A. \& McDonald, T. J. 1985: Gas hydrates of the Middle America trench - Deep sea drilling project Leg 84. In R. Nuene \& J. Aubouin, et al. Init. Repts DSDP 84, Washington U.S. Govt. Printing Office, 667-682.

Lein, A. Y., Galchenko, V. F., Pokrovsky, B. G., Shabayeva, I. Y. \& Chertkova, L. V. 1989: Marine carbonate nodules as a result of processes of microbe oxidizing of gas hydrate methane of the Sea of Okhotsk. Geochimia 10, 1396-1406. [In Russian].

Lein, A. Y., Galchenko, V. F., Grinenko, V. A., Ulyanova, N. V., Voropayeva, A. V. \& Guzhova, A. V. 1988: Mineral composition and geochemistry of rocks in the bacterial overgrowths from the submarine hydrothermal constructions. Geokhimia 9, 1235-1248. [In Russian].

Lisitsin, A. P., Binns, R. A., Bogdanov, Y. A., Scott, S., Zonenshayn, L. P., Gordeev, V. V., Gurvich, E. G., Muravyev, K. G. \& Serova, V. V., 1991: The present hydrothermal activity of Woodlark Sea (Papua-New Guinea). Izvestiya Akademii Nauk, s. Geologichescaya 8, 125-140. [In Russian].

Lisitsin, A. P., Bogdanov, Y. A. \& Gurvich, E. G., 1990: Hydrothermal deposits of ocean rift zones. Moscow, Nauka, 256 pp. [In Russian].

Lyon, G. L., Giggenbach, W. F., Singleton, R. J. \& Glasby, G. P. 1977: Isotopic and chemical composition of submarine geothermal gases from the Bay of Plenty, New Zealand. Geochemistry 1977. Bull. DSIR, New Zealand 218, 65-67.

Ozerova, N. A. 1977: Mercury degassing from the Earth interior. In Geochemistry of Ore Elements Migration Process. Moscow, Nauka, 15-35. [In Russian].

Romick, J. D., Tsvetkov, A. A., Seliverstov, N. I. \& Baranov, B. N. 1990: Silicic volcanism in the Komandorsky Basin: evidence for storage of a slab component in the backarc mantle. Contr. Min. Petr. 48, 218-255.

Rozhkov, A. M. \& Verhovsky, A. B. 1990: Geochemistry of noble gases of high-temperature thermal waters. Moscow, Nauka, 134 pp. [In Russian].
Sagalevich, A. M., Torokhov, P. V., Matveenkov, V. V., Calkin, S. V. \& Moskaliev, L. I. 1992: Hydrothermal activity of the Piip submarine volcano, Bering Sea. Izvestia Akademii Nauk, s. Geologia 9, 104-114. [In Russian].

Sakai, N., Gamo, T., Kim, E.-S., Tsutsumi, M., Tanaka, T., Ishibashi, J., Wakita, H., Yamano, M. \& Oomori, T. 1990: Venting of Carbon Dioxide rich fluid and hydrate formation in Mid-Okinawa through backarc basin. Science 248, 10931096.

Schoell, M. 1984: Stable isotopes in petroleum research. In I. J. Brooks \& D. Welte (eds) Advances in Petroleum Geochemistry. 1, Academic Press, London, 215-243.

Seliverstov, N. I., Avdeiko, G. P., Ivanenko, A. N., Shkira, V. A. \& Khubunaya, S. A. 1986: A new submarine volcano in the West sector of Aleutian arc. Volcanology and Seismology 4, 3-16. [In Russian].

Seliverstov, N. I., Baranov, B. V., Egorov, Y. O. \& Shkira, V. Y 1988: A new data on a structure of the South Komandorsky Basin based on the results of the $26 \mathrm{R} / \mathrm{V}$ "Vulkanolog" expedition. Volcanology and Seismology 4, 3-20. [In Russian].

Seliverstov, N. I., Gavrilenko, G. M. \& Kirianov, V. Y. 1989: Features of recent activity of Piip submarine volcano (Komandorsky Basin). Volcanology and Seismology 6, 3-18. [In Russian].

Shanks, W. C. \& Seyfried, W. E. 1987: Stable isotope studies of vent fluids and chimney minerals, Southern Juan de Fuca Ridge: sodium metasomatism and seawater sulfate reduction. J. Geophys. Res. 92, 11387-11399.

Taran, Y. A., 1988: Geochemistry of geothermal gases. Moscow, Nauka, 168 pp. [In Russian].

Taran, Y. A., Torokhov, P. V., Pokrovsky, B. G. \& Shabayeva, I. Y. 1992: Isotopic composition of mineral precipitates and free gas associeted with hydrothermal vents of Piip submarine volcano, Bering Sea. Geochem. Journ. 26, 291-297.

Torokhov, P. V. 1991: Sea water chemistry and other properties in the area of the submarine Vulkanologov Massif. Volc. Seis. $11(6), 898-912$.

Torokhov, P. V. 1992: Sulfide mineralization of hydrothermal deposits of the Piip volcano, Bering Sea. Doklady Akademii Nauk. 326/6; 1060-1063. [In Russian].

Torokhov, P. V., Taran, Y. A., Sagalevich, A. M., Pokrovsky, B. G. \& Shabayeva, I. Y. 1991: Isotope composition of methane, carbon dioxide and carbonates from thermal vents of Piip submarine volcano, Bering Sea. Doklady Akademii Nauk SSSR 318, 728-731. [In Russian].

Uchameishvili, N. E. \& Malinin, S. D. 1986: Formation conditions of Great Caucasus barite deposits. In B. P. Petrov \& I. S. Delicyn (eds) Barite. 22-29. [In Russian].

Vinogradov, V. I. 1980: Role of the sedimentary cycle in the sulfur isotope geochemistry. Moscow, Nauka, 192 pp. [In Russian].

Welhan, J. A. 1988. Origin of methane in hydrothermal systems. Chem. Geol. 71, 183-198.

Welhan, J. A. \& Craig, H. 1983: Methane, hydrogen and helium in hydrothermal fluids at $21^{\circ} \mathrm{N}$ on the East Pacific Rise. In P. A. Rona (ed.) Hydrothermal processes at seafloor spreading centers. N.Y. Plenum Press, 391-409.

Welhan, J. A. \& Lapton, J. E. 1987: Light hydrocarbon gases in Guaymas Basin hydrothermal fluids: thermogenic versus abiogenic origin. American Ass. Petrol. Geol. Bull. 71, 215223.

Wudruff, L. G. \& Shanks, W. C. 1988. Sulfur isotope study of chimney minerals and vent fluids from $21^{\circ} \mathrm{N}$, East Pacific Rise: hydrothermal sulfur sources and disequilibrium sulfate reduction. J. Geophys. Res. 93, 4562-4572. 